\title{
BOHUMIL VYKYPĚL
}

\section{STRUČNÁ POZNÁMKA K STAROČESKÝM SLABIČNÝM LIKVIDÁM}

COBISS: 1.03

\author{
Kratka pripomba k staročeškim zložnim likvidam \\ V članku je podana misel, da je pisanje zložnih likvid v stari češčini z vokalom gola gra- \\ fična konvencija, ki ima začetek v tujejezični interferenci. \\ Ključne besede: stara češčina, fonologija, grafematika, likvide, jezikovni stik
}

\begin{abstract}
A brief note on Old Czech syllabic liquids
This article suggests that the fact that Old Czech syllabic liquids were written with a vowel is a mere graphic convention resulting from foreign-language interference.

Keywords: Old Czech, phonology, graphemics, liquids, language contact
\end{abstract}

Paul Diels je asi znám především svou cennou gramatikou staroslověnštiny (srov. Diels 1932-34). Vedle toho byl však také autorem několika sice více či méně drobných, ale zato pozoruhodně inspirativních bohemistických textů. Jeden z těchto textů pojednává o jednom detailu $\mathrm{v}$ grafematicko-fonologickém popisu staré češtiny (srov. Diels 1911). Diels v něm ukazuje, že pravopis nejstarších staročeských jazykových památek důsledně rozlišuje mezi slabičnými a neslabičnými likvidami, když slabičné likvidy jsou psány pomocí $i r / y r$ a $i l / y l$, zatímco neslabičné jednoduchým $r$ a $l$. To, že byly v nejstarších památkách staré češtiny slabičné likvidy psány s $i$, př́ípadně $y$, je dobře známo a známo to bylo už za Dielsových časů (srov. Gebauer 1871: 34-38; 1894: 292-293; Dolanský 1899: 305). Č́m je ale Dielsova poznámka zajímavá, je dvojí.

Zaprvé je to skutečnost, že Diels bezprostředně srovnává psaní slabičných likvid s psaním neslabičných likvid a tak - vlastně nezáměrně a takříkajíc jako fonolog ante litteras - poukazuje na otázku fonologické hodnoty těchto hlásek ve staré češtině. Jak je známo, prèdstavovaly slabičné $r$ a neslabičné $r$ i slabičné $l$ a neslabičné $l$ ve staré češtině dva odlišné fonémy (a to na rozdíl od nové češtiny, kde se jedná o varianty jediného fonému $r$, respektive $l$ ) a tento jejich fonologický status se $\mathrm{v}$ grafice projevil tím, že slabičné likvidy byl občas psány zdvojeně, tedy $r r, l l$ (srov. Vykypěl 2016: kap. III). A právě odlišné psaní slabičných a neslabičných likvid v nejstarších staročeských jazykových památkách, na které poukazuje Diels, můžeme př́ípadně chápat tak, že se jím reflektuje zmíněná fonologická hodnota těchto hlásek. 
Tím přicházíme $\mathrm{k}$ druhému zajímavému bodu, $\mathrm{k}$ jehož promýšlení Dielsova poznámka podněcuje. Diels zjevně vychází z toho, že spojení $i / y+r, l$ označuje jednu hlásku, a tedy i jeden foném. Obvykle se ale toto psaní interpretuje tak, že i/y skutečně zachycuje nějaký doprovodný vokál, což se zároveň pokládá za svědectví pro to, že praslovanské slabičné likvidy byly ve staré češtině kontinuovány nejdřív spojením $i+$ likvida a teprve později se (zčásti) staly čistými slabičnými likvidami (srov. Havlík 1889: 443-444; Gebauer 1894: 292-293, 299-300; Trávníček 1935: 112-113); variantou tohoto pojetí je představa, že se jednalo pouze o doprovodný vokalický prvek, který př́padně byl potenciální povahy, takže daný hláskový jev je možno z fonologického hlediska považovat za jeden foném (srov. Komárek 1962: 60-61, 98-100). Avšak - inspirováni Dielsovou hláskoslovněfonologickou interpretací daného způsobu psaní - můžeme vyslovit domněnku, že doprovodné $i / y$ neodráží žádnou hláskovou skutečnost, ale představuje jen pravopisnou „pomůcku“ $\mathrm{k}$ rozlišení slabičných likvidových fonémů od likvidových fonémů neslabičných. Za svůj vznik taková pomůcka může přitom vděčit cizojazyčné (německé) percepci staročeských slabičných likvid (podobně Stieber 1957: 77); takové vysvětlení by pak posilovala ta okolnost, že právě v nejstarších staročeských jazykových památkách nacházíme pravopis, v němž zjevně na němčině bylo vystaveno psaní sykavek (srov. Vykypělová 2014: 18-22).

\section{LITERATURA}

Diels 1911 = Paul Diels, Zur altčechischen Orthographie, Archiv für slavische Philologie 32 (1911), $312-313$.

Diels 1932-34 = Paul Diels, Altkirchenslavische Grammatik 1-2, Heidelberg: Carl Winter, 19321934.

Dolanský 1899 = Ladislav Dolanský, O výslovnosti českého $i$ a y, Časopis Musea královstvi českého 73 (1899), 285-322.

Gebauer 1871 = Jan Gebauer, Př́spěvky k historii českého pravopisu a výslovnosti staročeské, Praha: nákladem musea království Českého, 1871 (Sborník vědecký musea království Českého, odbor historický, filologický a filosofický 4).

Gebauer 1894 = Jan Gebauer, Historická mluvnice jazyka českého 1, Praha - Vídeň: F. Tempský, 1894.

Havlík 1889 = Antonín Havlík, K otázce jerové v staré češtině, Listy filologické 16 (1889), 45-51, 106-116, 248-258, 342-353, 436-445.

Komárek 1962 = Miroslav Komárek, Historická mluvnice česká 1, Praha: Státní pedagogické nakladatelství, 21962.

Stieber 1957 = Zdzisław Stieber: Rozwój czeskiego systemu samogłoskowego, in: Tadeusz Lehr-Spławiński - Zdzisław Stieber, Gramatyka historyczna języka czeskiego 1, Warszawa: Państwowe Wydawnictwo Naukowe, 1957, 56-84.

Trávníček 1935 = František Trávníček, Historická mluvnice československá, Praha: Melantrich, 1935.

Vykypěl 2016 = Bohumil Vykypěl, Perspektiven auf die Geschichte des Tschechischen und die tschechische Geschichte, München: LINCOM, 2016 (LINCOM Studies in Slavic Linguistics 41).

Vykypělová 2014 = Tat'ána Vykypělová, Sechs Beiträge zur Geschichte des Tschechischen, München: LINCOM, 2014 (Travaux linguistiques de Brno 11). 


\section{PovZeTeK}

Kratka pripomba k staročeškim zložnim likvidam

V članku se motri staro opozorilo Paula Dielsa, da se v najstarejših staročeških spomenikih zložne likvide pišejo z i/y in se izraža dvoje mnenje: bodisi tako dvočrkje odraža en fonem bodisi tako zapisovanje izhaja iz tujejezične percepcije staročeških zložnih likvid. 